\title{
Gender role in pain perception and expression: an integrative review
}

\author{
Papel do gênero na percepção e expressão da dor: revisão integrativa
}

Michele Gomes Nascimento ${ }^{1}$, Maurício Kosminsky ${ }^{1}$, Michele Chi ${ }^{1}$

DOI 10.5935/2595-0118.20200013

\section{ABSTRACT}

BACKGROUND AND OBJECTIVES: Gender seems to play a role in influencing the response to experimental pain, although this influence is not very clear yet. Therefore, the objective of the present review was to investigate the contribution of the gender construct (gender identity/role) in the experience of pain through the selection and analysis of clinical studies on the subject.

CONTENTS: A search was carried out in the databases Medline (via Pubmed), LILACS (via BVS), and PsycINFO. The search used the following descriptors: gender identity, pain, gender role combined by the Boolean operator AND/OR (gender identity) AND pain AND gender role AND pain, in English, Portuguese and Spanish. At the end of the selection, 11 studies were included for this review. All the investigations recovered on the subject are clinical laboratory studies. Regarding the influence of the gender identity and its role in pain perception, most of the studies $(91 \%)$ show that this variable was a contributing factor to the differences observed in perception (tolerance/pain threshold) and the need to communicate the pain.

CONCLUSION: In experimental pain, a higher degree of femininity or female social roles are associated with lower thresholds and less tolerance to pain, as well as a greater natural tendency to communicate pain sensation. These results are independent of the type of stimulus, ethnicity, or sexual orientation.

Keywords: Gender and health, Gender identity, Pain.

\footnotetext{
Michele Gomes Nascimento - (Dhttps://orcid.org/0000-0003-2175-7080;

Maurício Kosminsky - (Dhttps://orcid.org/0000-0003-3111-7837;

Michele Chi - Dhttps://orcid.org/0000-0002-6045-0674.

1. Universidade de Pernambuco, Departamento de Dor Orofacial, Recife, PE, Brasil.

Submitted on July 12, 2019.

Accepted for publication on September 18, 2019.

Conflict of interests: none - Sponsoring sources: none.

Correspondence to:

Rua José Carvalheira, 250/201

52051-060 Recife, PE, Brasil.

E-mail: michelepmpe@yahoo.com.br michelechi96@gmail.com

(C) Sociedade Brasileira para o Estudo da Dor
}

\section{RESUMO}

JUSTIFICATIVA E OBJETIVOS: A identidade de gênero e o seu papel aparentam influenciar a resposta à dor experimental, embora ainda não seja claro a magnitude dessa influência. Assim, o objetivo deste estudo foi investigar a influência do construto gênero (identidade/papel de gênero) na experiência da dor mediante a seleção e análise de estudos clínicos sobre o tema.

CONTEÚDO: Foi desenvolvida uma busca nas bases de dados Medline (via Pubmed), LILACS (via BVS), PsycINFO. A busca foi desenvolvida com os seguintes descritores: tender identity, pain, gender role combinados pelo operador booleano $A N D / O R$ (gender identity) $A N D$ pain $O R$ (gender role) $A N D$ pain. Os idiomas selecionados foram inglês, português e espanhol. Ao final da seleção, 11 estudos foram incluídos. Todas as investigaçóes recuperadas sobre a temática compreenderam estudos clínicos laboratoriais. Em relação à influência da identidade e papel de gênero na percepção dolorosa, a maioria dos estudos (91\%) encontraram que essa variável foi fator contribuinte para as diferenças observadas na percepção (tolerância/limiar de dor) e necessidade de comunicar a dor.

CONCLUSÃO: Em dor experimental, maior feminilidade ou papéis sociais femininos estão associados a menores limiares e menor tolerância à dor, assim como maior propensão de comunicar a sensaçáo dolorosa. Esses resultados independem do tipo de estímulo, da etnia ou orientação sexual.

Descritores: Dor, Gênero e saúde, Identidade de gênero.

\section{INTRODUCTION}

Pain is a symptom present in a wide range of medical conditions and can have a significant impact on a person's quality of life and overall functioning ${ }^{1}$. Women have a higher prevalence of chronic pain-related diagnoses ${ }^{1-4}$, and research has consistently shown gender differences, such as pain perception, description and expression, the use of coping strategies, and the benefit of different treatments ${ }^{2,5-7}$. Biological differences may contribute to gender differences ${ }^{2,3,7}$. Genetic factors, as well as hormonal factors, act as gender-specific pain mediators ${ }^{2,3,5}$. Studies indicate that women's pain responses are affected by the menstrual cycle, pregnancy, and oral contraceptive use $\mathrm{e}^{5,8-10}$, which considers that hormones are related to pain response. Additionally, the response to opioid receptor antagonists may generate differences in pain experiences between men and women ${ }^{3,5,10}$.

Pain is, by definition, always subjective ${ }^{11}$. Scales, widely used to assess pain in research and clinical practice ${ }^{2,12,13}$, measure pain reporting, which in turn may be influenced by psychosocial factors such as gender. From an early age, boys and girls are socia- 
lized along with gender norms of how to respond to pain. Boys and men learn to be tough, tolerate pain, and sustain painful experiences, while girls and women are socialized to be sensitive, caring, and to verbalize discomfort ${ }^{14}$.

The terms "sex" and "gender" refer to two distinct but related factors. Sex encompasses a set of biological attributes such as chromosomes, gene expression, and anatomical aspects. Gender refers to the attitudes, feelings, and behaviors that a given culture associates with a person's biological sex. It is related to a complex context, being dependent on psychological, psychosocial, cultural, and political factors, being defined as a sociocultural construction of roles, norms, behaviors, identities, and power relations ${ }^{15,16}$. Gender identity refers to a person's inner sense of being man, woman, female or male, or otherwise. Gender expression refers to how a person reports gender identity to others through behavior, clothing, hairstyles, voice, or body characteristics. In turn, the role of gender refers to the way society, in a given time or culture, considers the femininity/masculinity of the individual ${ }^{17}$.

Despite the growing literature on the theme, few studies have been conducted to identify the influence of gender on pain. Understanding the mechanisms associated with these differences may, in the future, provide more realistic data for epidemiological studies and direct to more specific treatments.

This study aimed to investigate the contribution of the gender construct (gender identity/role) in the pain experience by selecting and analyzing clinical trials on the theme.

\section{CONTENTS}

In order to achieve the proposed objectives, an integrative literature review was chosen, a method that provides the synthesis of knowledge, as it enables the gathering of results from significant studies. The steps that guided its development were: 1- elaboration of the guiding question, 2- establishment of inclusion and exclusion criteria of articles, 3- definition of the information to be extracted from the selected studies, 4- critical analysis of the included studies, 5- analysis, synthesis and presentation of results ${ }^{18}$.

The guiding question of the research was: "what is the contribution of gender in pain responses and experiences for both sexes"? Study selection was limited to publications in English, Portuguese, and Spanish. Reviews and meta-analyses were excluded from the sample. The last consultation of the publications was between June and August 2018. The selected databases were Medline (via Pubmed), LILACS (via VHL), and PsycINFO. The search was performed with the following keywords: 'gender identity', 'gender role' and 'pain' combined by boolean operator OR/AND (((gender identity[MeSH Terms]) OR gender roles[MeSH Terms])) AND pain[MeSH Terms]. Original studies involving humans, without age limit that used in their methodology some instrument to assess gender identity or gender role, and/or femininity and/or masculinity, and the relationship with pain were included.

The selection of publications was conducted in three phases: double-reading title selection, abstracts, qualitative analysis of the full texts. The analysis process for the assessment and selection of articles was performed by two researchers independently, with subsequent comparison of results to obtain the texts selected by consensus. A third researcher evaluator was invited to participate in cases of disagreement or doubts about the inclusion of the work.

At the end of the selection process, 123 articles listed in Medline and four in LILACS were identified, four of which were duplicates. After the double-reading of title selection, 42 articles were selected, and 81 articles were excluded. After reading the titles and abstracts of these articles, 27 references were selected for the full reading. Eleven studies were included in the qualitative synthesis. The process of study selection can be observed in figure 1.

The titles were excluded for: not contemplating the theme (81); studies evaluating only gender (15); studies that did not evaluate the relationship between gender and pain (16) and duplicates (4).

At the end of the selection, 11 studies were included. All investigations retrieved on the theme comprised of laboratory studies. Regarding the years of publication, the distribution was one article for the years 2002, 2003, 2004, 2006, 2012, 2013, 2014, and two for the years 2009 and 2011. In the analysis of the countries that investigated the theme, the distribution was as follows: United States (7), Israel (2), and the United Kingdom (2).

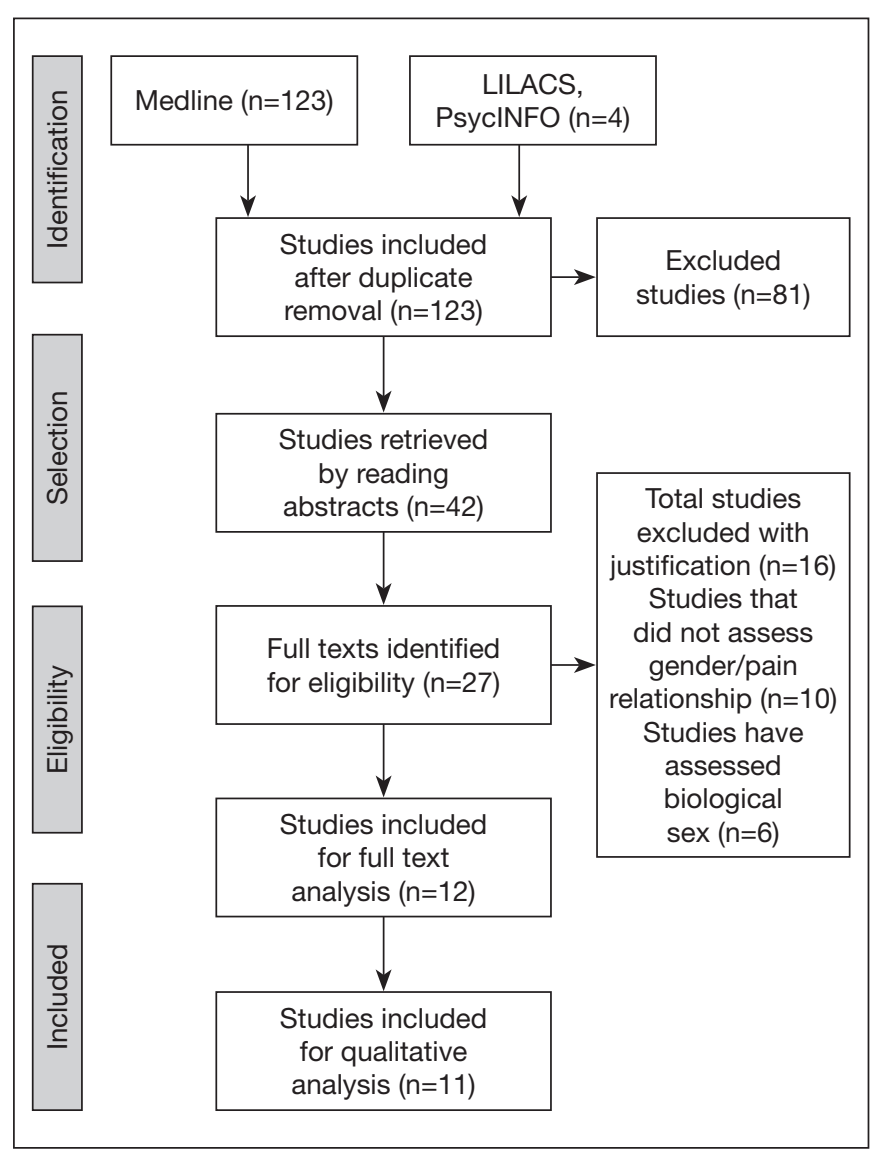

Figure 1. Identification of studies according to databases and eligibility criteria $^{19}$ 
The study sample ranged from 67 to 548 participants. Concerning the age group, ten studies were with adult individuals (18-45 years old) and only one with children (8-18 years old). Regarding the study design, all articles were of the clinical trial type, with nine prospective nonrandomized, one prospective randomized, and one retrospective nonrandomized.

Seven different instruments were identified to assess gender identity and role. Most (six) used the Gender Role Expectation of Pain (GREP). The Bem Sex-Role Inventory (BSRI) was used in two studies, while the other studies used distinct instruments: Personal Attributes Questionnaire, Hypermasculinity Index, Child Sex-Role Inventory, and Balanced Inventory of Desirable Responding. One study applied questions about gender expression, the level of masculinity/femininity preferred for a romantic partner, how one describes oneself concerning masculinity/femininity.
For pain analysis, the most used instrument was the visual analog scale (VAS) in seven articles. Other research has applied different instruments: Short-Form of the McGill Pain Questionnaire, Pain Tolerance Assessment, and Quantitative Somatosensory Testing. Only one study did not use a standardized instrument. The pain threshold was sensitively measured by pain tolerance time.

All studies were with healthy subjects, where the pain was caused by different types of stimuli. The most frequently used stimulus was thermal (six studies). Also, other studies caused the pain sensation by pressure, ischemia and/or electric shock. Regarding the influence of gender identity and its role on pain perception, most studies (91\%) found that this variable was a contributing factor to perceived differences (pain tolerance/ threshold) and the need to report pain. The results are presented in table 1 .

Table 1. Distribution of studies

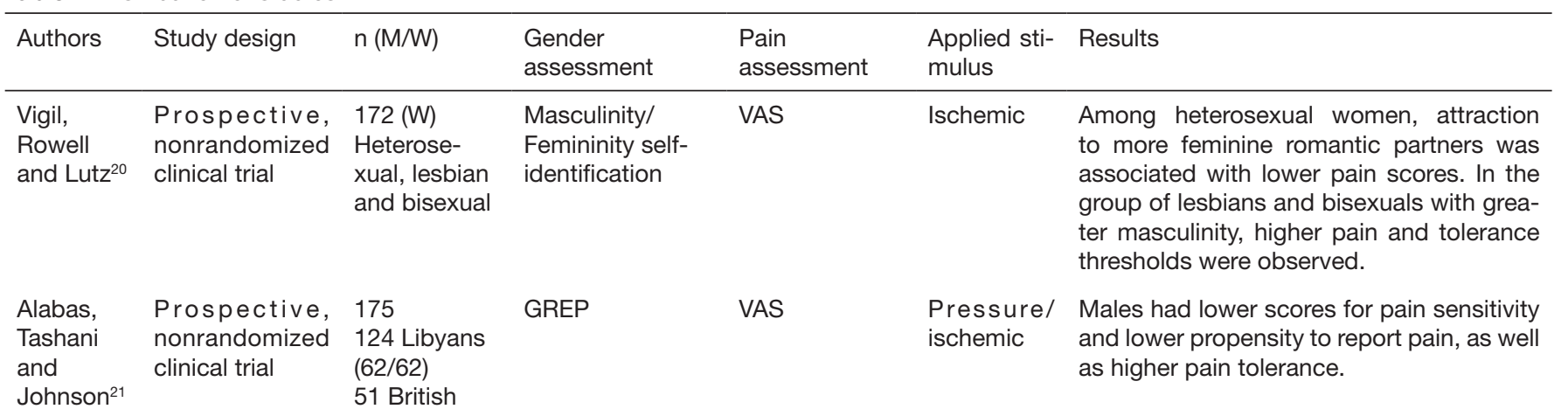

Alabas,

Tashani

and

Prospective (25/26)

$114(56 / 58) \quad$ GREP

VAS

nonrandom
clinical trial

Defrin, Eli

Retrospective,

$548(210 / 338)$

GREP

nonrandomized 341 Jews

clinical trial

105 Arab

Muslims

102 Arab-

Christians

Fowler et Prospective, $89(45 / 44)$

al. ${ }^{24}$

randomized cli-

nical trial

$\begin{array}{lll}\begin{array}{l}\text { Defrin, } \\ \text { Shramm } \\ \text { and Eli }\end{array} & \begin{array}{l}\text { Prospective, } \\ \text { nonrandomized } \\ \text { clinical trial }\end{array} & 72(33 / 39) \\ \begin{array}{l}\text { Reidy et } \\ \text { al. }^{26}\end{array} & \begin{array}{l}\text { Prospective, } \\ \text { nonrandomized } \\ \text { clinical trial }\end{array} & 195(65 / 130) \\ \begin{array}{l}\text { Myers et } \\ \text { al. }{ }^{27}\end{array} & \begin{array}{l}\text { Prospective, } \\ \text { nonrandomized } \\ \text { clinical trial }\end{array} & \begin{array}{l}\text { (120/120) } \\ \end{array}\end{array}$

GREP

Hypermasculinity Index

Child Sex Role

Inventory
VAS

Short-Form of the McGill Pain Questionnaire

HPT/ HPTL

Pain Tolerance Electric Assessment

VAS (cold)

Thermal Despite cultural differences, they did not (cold) influence responses to pain. Libyan (African) women were more likely to report pain, more sensitive and less tolerant. Libyan men showed greater tolerance and thresholds for cold pain.

Regardless of the religious ethnic group, the "typical" man considered woman to be more sensitive to pain. Men considered themselves less likely to report pain.

The r m a I Sex and gender roles interacted in such a way that men reported lower pain sensitivity and less anxiety, but only when prepared with a female gender role.

Thermal Individuals with greater masculinity had (heat) greater pain tolerance and less need to report pain.

Pain tolerance was significantly and positively related to traits of aggression in men, unlike women.

Pressure/ For boys, but not among girls, there was $\mathrm{t} \mathrm{h}$ e r m a I a significant negative correlation between (cold/heat) masculinity and pain scores; as the masculinity score increased, pain self-reports decreased. 
Table 1. Distribution of studies - continuation

\begin{tabular}{|c|c|c|c|c|c|c|}
\hline Authors & Study design & $\mathrm{n}(\mathrm{M} / \mathrm{W})$ & $\begin{array}{l}\text { Gender } \\
\text { assessment }\end{array}$ & $\begin{array}{l}\text { Pain } \\
\text { assessment }\end{array}$ & $\begin{array}{l}\text { Applied sti- } \\
\text { mulus }\end{array}$ & Results \\
\hline $\begin{array}{l}\text { Robinson } \\
\text { et al. }{ }^{28}\end{array}$ & $\begin{array}{l}\text { Prospective, } \\
\text { nonrandomized } \\
\text { clinical trial }\end{array}$ & $67(37 / 30)$ & GREP & VAS & $\begin{array}{l}\text { Therm a I } \\
\text { (heat) }\end{array}$ & $\begin{array}{l}\text { The propensity to report pain was a signifi- } \\
\text { cant predictor of the magnitude of tempo- } \\
\text { ral summation, regardless of sex. Women } \\
\text { showed greater temporal summation to } \\
\text { thermal stimuli. }\end{array}$ \\
\hline $\begin{array}{l}\text { Wise et } \\
\text { al. }^{29}\end{array}$ & $\begin{array}{l}\text { Prospective, } \\
\text { nonrandomized } \\
\text { clinical trial }\end{array}$ & $148(61 / 87)$ & GREP & VAS & $\begin{array}{l}\text { Th e r m a I } \\
\text { (heat) }\end{array}$ & $\begin{array}{l}\text { Expectations related to male gender were } \\
\text { predictors of higher pain thresholds and } \\
\text { pain tolerance, regardless of gender. }\end{array}$ \\
\hline $\begin{array}{l}\text { Myers et } \\
\text { al. }^{30}\end{array}$ & $\begin{array}{l}\text { Prospective, } \\
\text { nonrandomized } \\
\text { clinical trial }\end{array}$ & $104(54 / 50)$ & BSRI & $\begin{array}{l}\text { Tolerance time } \\
\text { in seconds }\end{array}$ & $\begin{array}{l}\text { Therm a I } \\
\text { (cold) }\end{array}$ & $\begin{array}{l}\text { Although the gender role was a predictor } \\
\text { of pain tolerance, it was not a predictor of } \\
\text { pain differences between the sexes. }\end{array}$ \\
\hline
\end{tabular}

VAS = visual analog scale; GREP = Gender Role Expectation of Pain; BSRI = Bem Sex Role Inventory; PAQ = Personal Attributes Questionnaire; HPT = Heat-Pain Threshold; HPTL = Heat-Pain Tolerance Limit.

\section{DISCUSSION}

This review aimed to identify whether gender (gender identity or roles) influences pain perception. According to the criteria used for the inclusion of studies, only investigations of experimental pain in healthy individuals could be retrieved. Most studies indicated that gender was a contributing factor to the differences observed in pain perception, despite the different stimuli applied. In general, the results showed an association between a higher degree of femininity and a greater perception of painful stimuli, regardless of gender. For individuals with a higher degree of masculinity, higher thresholds and pain tolerance were observed, as well as a lower propensity to report pain.

In all studies analyzed, the variables considered in experimental pain included: pain induction method, pain measurements used, laboratory environment influences, typified experimenter appearance, and possible individual biases. Due to the multiple sources of variability, it was evident that inconsistent patterns of pain responsiveness exist in the literature. Differences in the reporting of experimental pain in men and women are believed to result from an influence of the laboratory environment, where psychosocial constructs are activated differently between the sexes. Differences may be due mainly to gender-specific socialization patterns concerning pain beliefs, expectations, and subsequent behaviors. Thus, men who adhere to the male role are expected to underreport pain. On the other hand, following a female role would allow women to verbalize their pain reports. However, these reports are mainly speculative and the lack of controls in the studies makes it difficult to conclude on sex differences.

Although biological mechanisms have been postulated to explain these variabilities, it is suggested that social learning may be a stronger influence on pain response. During puberty, incipient gender differences in pain tolerance seem especially attributable to lower pain threshold in girls. Decreasing thresholds for girls may reflect specific changes in pain perception and pain assessment associated with puberty (due to hormonal influences or changes in gender role orientations). Another point that should be emphasized is that the individual's pain threshold did not influence pain resistance. A person reporting early pain experiences during a stimulus is also expected to experience decreased resis- tance. However, there seems to be a low correlation between pain threshold and resistance ${ }^{32}$. Social norms dictate that men should be stoic, making it unlikely that they report pain or express it emotionally. On the other hand, social rules allow women to be emotionally expressive when in pain and seek medical attention to relieve it.

Thus, one should be able to predict pain-related behaviors of an individual's gender group and the relative importance of adhering to group norms.

For gender analysis, most studies applied the GREP instrument designed to identify sexual differences in relation to pain expectations, both for others and themselves. This instrument analyzes five factors: pain sensitivity, willingness to report pain, pain sensitivity self-report, pain resistance self-report, and stereotyped pain resistance. The results of this study indicated that in all interventions, GREP mediated different pain reactions for both men and women. Based on social learning theory, men must tolerate more severe pain. Women also consider men, in general, to be more tolerant to pain, less willing to report pain, and less sensitive to $\mathrm{it}^{32}$.

To a lesser extent, for the gender assessment, the BSRI instrument was applied in two studies. One study pointed out that while gender was a predictor of pain tolerance, it was not a predictor of pain differences between the sexes. In fact, the authors stated that the construct identified by BSRI is a global measure related to personality traits. Considering that gender-related pain behavior is flexible and context-dependent; therefore, the BSRI would not assess gender aspects that are specifically elucidated in the experimental pain task $\mathrm{k}^{33}$. In another study that used the same painful (cold) stimulus and the BSRI instrument for gender assessment, it was observed that men reported lower pain sensitivity and less anxiety compared to women, but only when "prepared" with a female role. For example, the ability to bear pain may be amplified by the presence of a female suggestion. Men would show a higher tolerance for an experimental pain stimulus after being informed in advance that women have a higher tolerance in that situation ${ }^{34}$.

As observed in the results (Table 1), a smaller portion of studies analyzed other possible confounding variables, such as ethnic and cultural differences, and sexual orientation. However, they 
did not influence the response to pain. In a systematic review of racial and ethnic differences in experimental pain sensitivity, the authors noted that experimental and racial/ethnic differences in experimental pain sensitivity are more pronounced in supra-threshold pain experiences than in thresholds. This may be important because supraliminal pain measures have been reported as one of the most relevant experimental tasks for clinical pain ${ }^{34}$. This study elucidated some aspects pertinent to experimental pain, which behavior differs significantly from clinical pain, especially chronic pain. It is noteworthy that pain threshold and pain intensity classifications are commonly considered indicative of the sensory-discriminative pain characteristic, while tolerance and discomfort classifications are considered indicative of the affective and motivational aspects of pain. The results of this study highlight the importance of further studies on clinical pain that assess the gender construct in its self-identification and behavioral aspects to understand the higher prevalence and higher risk of chronic pain in females. Factors such as the examiner's qualities should also be better reported in studies. Although it is difficult to control all confounding variables, it is essential to identify the biological and social aspects related to the participants' gender to understand the phenomenon better.

\section{CONCLUSION}

In experimental pain, higher femininity or female social roles seem to be associated with lower pain tolerance and lower pain tolerance thresholds, as well as a greater propensity to report painful sensation. These results do not depend on the type of stimulus, ethnicity or sexual orientation.

\section{REFERENCES}

1. Breivik H, Collett B, Ventafridda V, Cohen R, Gallacher D. Survey of chronic pain in Europe: prevalence, impact on daily life, and treatment. Eur J Pain. 2006;10(4):287333.

2. Fillingim RB, King CD, Ribeiro-Dasilva MC, Rahim-Williams B, Riley JL 3rd. Sex, gender, and pain: a review of recent clinical and experimental findings. J Pain. 2009;10(5):447-85.

3. Greenspan JD, Craft RM, LeResche L, Arendt-Nielsen L, Berkley KJ, Fillingim RB, et al. Studying sex and gender differences in pain and analgesia: a consensus report. Pain. 2007;132(Suppl1):S26-45.

4. Cimmino MA, Ferrone C, Cutolo M. Epidemiology of chronic musculoskeletal pain. Best Pract Res Clin Rheumatol. 2011;25(2):173-83.

5. Hurley RW, Adams MC. Sex, gender, and pain: an overview of a complex field. Anesth Analg. 2008;107(1):309-17.

6. Bernardes SF, Keogh E, Lima ML. Bridging the gap between pain and gender research: a selective literature review. Eur J Pain. 2008;12(4):427-40.

7. Bartley EJ, Fillingim RB. Sex differences in pain: a brief review of clinical and experimental findings. Br J Anaesth. 2013;111(1):52-8.

8. Barsky AJ, Peekna HM, Borus JF. Somatic symptom reporting in women and men. J Gen Inter Med. 2001;16(4):266-75.
9. Keogh E. Sex and gender differences in pain: a selective review of biological and psychosocial factors. J Men's Health Gender. 2006;3(3):236-43.

10. Racine M, Tousignant-Laflamme Y, Kloda LA, Dion D, Dupuis G, Choinière M. A systematic literature review of 10 years of research on sex/gender and pain perception part 2: do biopsychosocial factors alter pain sensitivity differently in women and men? Pain. 2012;153(3):619-35.

11. Merskey H, Bogduk N. Classification of chronic pain, IASP Task Force on Taxonomy. Seattle, WA: International Association for the Study of Pain Press (Also available online at www.iasp-painorg). 1994.

12. Richardson J, Holdcroft A. Gender differences and pain medication. Womens Health 2009;5(1):79-90.

13. Hoffmann DE, Tarzian AJ. The girl who cried pain: a bias against women in the treatment of pain. J Law Med Ethics. 2001;29(1):13-27.

14. Myers CD, Riley JL 3rd, Robinson ME. Psychosocial contributions to sex-correlated differences in pain. Clin J Pain. 2003;19(4):225-32.

15. Marmot M, Friel S, Bell R, Houweling TA, Taylor S. Closing the gap in a generation: health equity through action on the social determinants of health. Lancet. 2008;372(9650):1661-9.

16. Day S, Mason R, Tannenbaum C, Rochon PA. Essential metrics for assessing sex \& gender integration in health research proposals involving human participants. PLoS One. 2017;12(8):e0182812.

17. Fidler F. The American Psychological Association publication manual sixth edition implications for statistics education. Data and context in statistics education: towards an evidence-based society. 2010.

18. Souza MT, Silva MD, Carvalho Rd. Integrative review: what is it? How to do it? Einstein. 2010;8(1):102-6. English, Portuguese.

19. Moher D, Liberati A, Tetzlaff J, Altman DG. Preferred reporting items for systematic reviews and meta-analyses: the PRISMA statement. PLoS Med. 2009;6(7):e1000097.

20. Vigil JM, Rowell LN, Lutz C. Gender expression, sexual orientation and pain sensitivity in women. Pain Res Manag. 2014;19(2):87-92.

21. Alabas OA, Tashani OA, Johnson MI. Effects of ethnicity and gender role expectations of pain on experimental pain: a cross-cultural study. Eur J Pain. 2013;17(5):776-86.

22. Alabas OA, Tashani OA, Johnson MI. Gender role expectations of pain mediate sex differences in cold pain responses in healthy Libyans. Eur J Pain. 2012;16(2):300-11.

23. Defrin R, Eli I, Pud D. Interactions among sex, ethnicity, religion, and gender role expectations of pain. Gend Med. 2011;8(3):172-83.

24. Fowler SL, Rasinski HM, Geers AL, Helfer SG, France CR. Concept priming and pain: an experimental approach to understanding gender roles in sex-related pain differences. J Behav Med. 2011;34(2):139-47.

25. Defrin R, Shramm L, Eli I. Gender role expectations of pain is associated with pain tolerance limit but not with pain threshold. Pain. 2009;145(1-2):230-6.

26. Reidy DE, Dimmick K, MacDonald K, Zeichner A. The relationship between pain tolerance and trait aggression: effects of sex and gender role. Aggress Behav. 2009;35(5):422-9.

27. Myers CD, Tsao JC, Glover DA, Kim SC, Turk N, Zeltzer LK. Sex, gender, and age: contributions to laboratory pain responding in children and adolescents. J Pain. 2006;7(8):556-64.

28. Robinson ME, Wise EA, Gagnon C, Fillingim RB, Price DD. Influences of gender role and anxiety on sex differences in temporal summation of pain. J Pain. 2004;5(2):77-82.

29. Wise EA, Price DD, Myers CD, Heft MW, Robinson ME. Gender role expectations of pain: relationship to experimental pain perception. Pain. 2002;96(3):335-42.

30. Myers CD, Robinson ME, Riley JL 3rd, Sheffield D. Sex, gender, and blood pressure: contributions to experimental pain report. Psychosom Med. 2001;63(4):545-50.

31. Schmitz AK, Vierhaus M, Lohaus A. Pain tolerance in children and adolescents: sex differences and psychosocial influences on pain threshold and endurance. Eur J Pain. 2013;7(1):124-31

32. Pool GJ, Schwegler AF, Theodore BR, Fuchs PN. Role of gender norms and group identification on hypothetical and experimental pain tolerance. Pain. 2007;129(12):122-9.

33. Robinson ME, Riley III JL, Myers CD, Papas RK, Wise EA, Waxenberg LB, et al. Gender role expectations of pain: relationship to sex differences in pain. J Pain. 2001;2(5):251-7.

34. Kim HJ, Yang GS, Greenspan JD, Downton KD, Griffith KA, Renn CL, et al. Racia and ethnic differences in experimental pain sensitivity: systematic review and meta-analysis. Pain. 2017;158(2):194-211. 